\title{
PENGARUH PIRANTI FUNGSIONAL LEPASAN TERHADAP PERUBAHAN PANJANG MANDIBULA
}

Yufridika*, Erna Sulistyawati**, Muslim Yusuf ${ }^{* *}$

\begin{tabular}{c} 
Keywords: \\
class II malocclusion, \\
removable functional \\
appliance, total \\
mandibular length, \\
mandibular corpus \\
length \\
\hline
\end{tabular}

ABSTRACT

Background: Class II malocclusion prevalence is about $70 \%$. Class II malocclusion could be caused by retrognatic mandible and normal maxilla, prognatic maxilla and normal mandible or combination of retrognatic mandible and prognatic maxilla. Class II malocclusion can be treated with fixed or removable functional appliance on advancing mandibular length. Aim: To examine the effect of functional appliance in mandibular length.

Method: Age of sample is ranging from 7-13 years old treated using removable functional appliance with proper and complete medical record. In this research, a purposive sampling method was used. The mandibular length changes of samples were evaluated and analyzed with statistical computerized system.

Result: The research reveals that total mandibular length was changed by 7.09 $\mathrm{mm}$ while mandibular corpus length was changed by $3.27 \mathrm{~mm}$. Based on paired t-test, these results are found to be statistically significant $(p<0.05)$.

Conclusion: The removable functional appliance on samples with Class II malocclusion contributes a significant effect both for total mandibular and corpus mandibular length

\section{PENDAHULUAN}

Maloklusi Klas II dapat berupa anomali skeletal maupun dental, namun sering merupakan kombinasi kelainan dental dan skeletal. Morfologi Klas II dapat berupa mandibula retrognati, maksila prognati atau kombinasi keduanya. ${ }^{1-5}$ Oshagh $\mathrm{dkk}$ menyatakan prevalensi maloklusi skeletal Klas II sebesar $70 \% .^{2-3}$ Pilihan perawatan pada maloklusi Klas II dengan overjet besar disertai mandibula retrognati adalah piranti fungsional. ${ }^{1-5}$ Perawatan maloklusi Klas II dengan piranti fungsional dengan memajukan mandibula ke anterior menurut McNamara cenderung memiliki tingkat keberhasilan yang lebih tinggi dibandingkan perawatan yang menghambat pertumbuhan maksila. ${ }^{6-7}$

Piranti fungsional baik cekat maupun lepasan dapat digunakan untuk koreksi skeletal pada usia tumbuh kembang. Berbagai jenis piranti fungsional lepasan dapat digunakan untuk merangsang pertumbuhan mandibula ke anterior untuk mengoreksi maloklusi skeletal maupun dental. Waktu yang optimal untuk mendapatkan efek perawatan pada pasien usia tumbuh kembang sebaiknya dimulai pada tahap awal maturasi fisiologis CV3 vertebra servikalis. ${ }^{4,5,8}$

Radiografi sefalometri lateral digunakan untuk mengevaluasi pertumbuhan yang berhubungan dengan kompleks kraniofasial. Tingkat keberhasilan perawatan fungsional lepasan dapat diamati dengan perubahan besar sudut ANB. Ahlgren dan Laurin menyatakan nilai ANB merupakan satusatunya kriteria morfologis untuk membedakan kasus yang berhasil dan yang tidak berhasil dirawat. Variabel lain yang mempengaruhi perubahan sudut ANB adalah pola rotasi vertikal pertumbuhan mandibula. ${ }^{2,9,10}$

Total panjang mandibula atau total

${ }^{*}$ Residen Program Pendidikan Dokter Gigi Spesialis Ortodonsia. Fakultas Kedokteran Gigi USU. ** Staff Pengajar Program Pendidikan Dokter Gigi Spesialis Ortodonsia. Fakultas Kedokteran Gigi USU Korespondensi: yufridika@ymail.com 
mandibular length didefinisikan sebagai jarak linear antara Condylion/Co yaitu titik paling superior pada kondilus terhadap pogonion/ Pog yaitu titik paling anterior dari dagu. Panjang korpus mandibula merupakan jarak linear antara gonion dan pogonion. Caldwell dkk menyatakan pada sudut SNB yang kecil dan overjet yang besar sebelum perawatan terjadi perubahan yang signifikan berupa bertambah besarnya sudut SNB dan overjet yang makin mengecil dengan pemakaian piranti fungsional lepasan. Terjadi perbaikan estetika wajah akibat terkoreksinya maloklusi Klas II dengan profil retrognati menjadi maloklusi skeletal Klas I dengan profil ortognati. 5,11,12

\section{METODE PENELITIAN}

Obyek penelitian berupa foto sefalometri lateral sebelum dan setelah selesai perawatan dengan menggunakan piranti fungsional lepasan berupa activator, bionator, twin block serta frankel pada maloklusi skeletal Klas II di Rumah Sakit Gigi dan Mulut Fakultas Kedokteran Gigi Universitas Sumatera Utara tahun 2006-2017, dengan kriteria subjek sebagai berikut: 1) Usia 7-13 tahun. 2) retrognati mandibula/SNB $<78,3$ ) pasien telah selesai perawatan piranti fungsional lepasan. Penapakan pada kertas asetat dengan pensil $4 \mathrm{H}$ di atas iluminator.

Adapun bidang dan titik referensi pada penilitian ini adalah: 1) titik S: Sella; 2) titik N: Nasion; 3) titik B; 4) titik A; 5) titik Go: Gonion; 6) Gn: Gnation; 7) Co: Condylion; 8) titik Pog: Pogonion; 9) bidang SN; 10) bidang dataran mandibula/MP:SN; 11) panjang korpus mandibula/Go-Gn; 12) Total panjang mandibula/Co-Pog.

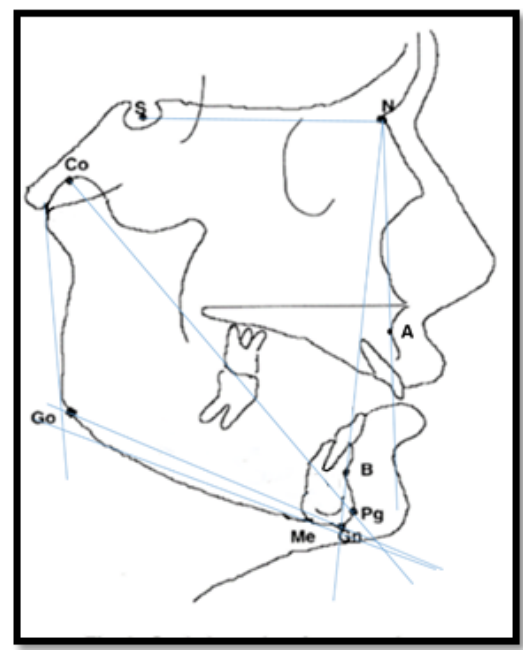

Gambar 1. Bidang dan titik referensi penelitian.

Tabel 1. Pengukuran titik dan bidang referensi pada pemakaian piranti fungsional lepasan.

\begin{tabular}{lcccccc} 
Variabel & N & Mean & SD & P & \multicolumn{2}{c}{$\begin{array}{c}\text { Confidence Interval 95\% } \\
\text { Lower }\end{array}$} \\
& & & & & Upper \\
\hline Panjang Korpus Mandibula & 13 & 3,27 & 1,48 & \multirow{2}{*}{000} & 5,68 & 1,95 \\
Total Panjang Mandibula & 13 & 7,09 & 2,98 & & & \\
\hline perubahan yang signifikan $(\mathrm{p}<.05)$ & & & & &
\end{tabular}


Tabel 2. Perubahan total panjang mandibula dan panjang korpus mandibula.

\begin{tabular}{|c|c|c|c|c|}
\hline Variabel & $\mathrm{N}$ & Mean & SD & $\mathrm{P}$ \\
\hline Pre SNA $\left({ }^{\circ}\right)$ & 13 & 81,46 & 2,02 & \multirow{2}{*}{.273} \\
\hline Post SNA $\left(^{\circ}\right)$ & 13 & 81,23 & 1,64 & \\
\hline Pre SNB $\left(^{\circ}\right)$ & 13 & 74,69 & 1,65 & \multirow{2}{*}{$.000^{*}$} \\
\hline Post SNB $\left({ }^{\circ}\right)$ & 13 & 77,84 & 1,77 & \\
\hline Pre ANB $\left(^{\circ}\right)$ & 13 & 6,76 & 2,72 & \multirow{2}{*}{$.000^{*}$} \\
\hline Post ANB $\left({ }^{\circ}\right)$ & 13 & 3,76 & 2,12 & \\
\hline Pre MP:SN $\left({ }^{\circ}\right)$ & 13 & 34,76 & 4,65 & \multirow{2}{*}{.891} \\
\hline Post MP:SN $\left(^{\circ}\right)$ & 13 & 34,84 & 5,11 & \\
\hline Pre Total Panjang Mandibula (mm) & 13 & 104,12 & 6.01 & \multirow{2}{*}{$.000^{*}$} \\
\hline Post Total Panjang Mandibula (mm) & 13 & 111,20 & 5,58 & \\
\hline Pre Panjang Korpus Mandibula (mm) & 13 & 72,10 & 6,42 & \multirow{2}{*}{$.000 *$} \\
\hline Post Panjang Korpus Mandibula (mm) & 13 & 75,37 & 6,99 & \\
\hline
\end{tabular}

\section{HASIL PENELITIAN}

Perawatan maloklusi skeletal Klas II retrognati mandibula usia tumbuh kembang dengan piranti fungsional lepasan terlihat terjadinya perubahan signifikan baik pada total panjang mandibula maupun panjang korpus mandibula $(p<0,05)$. Dari hasil penelitian ini juga terlihat adanya perubahan anteroposterior maksila/SNA dan perubahan vertikal pola rotasi mandibula/MP:SN tetapi perubahan ditemukan tidak signifikan $(P>0,05)$ (tabel 1 dan tabel 2).

\section{DISKUSI}

Prinsip perawatan maloklusi skeletal klas II retrognati mandibula yaitu merangsang pertumbuhan mandibula ke anterior. Selain untuk mendapatkan perubahan relasi skeletal dan oklusi yang lebih baik yaitu Klas I, juga untuk mencapai profil wajah ortognati yang diperoleh dengan mekanisme perawatan fungsional lepasan maupun aktivitas otot-otot kraniofasial. Perubahan-perubahan morfologi kraniofasial yang terjadi pada perawatan maloklusi skeletal Klas II retrognati mandibula dengan menggunakan piranti lepasan seperti activator, twinblock, frankel dan bionator dapat terjadi pertambahan total panjang mandibula maupun panjang korpus mandibula serta pengurangan suduit ANB yang signifikan. Sistem perawatan fungsional lepasan juga memberikan hasil penghambatan pertumbuhan maksila, dan bertambahnya dimensi vertikal rotasi mandibula tetapi hasilnya tidak signifikan. Sistem perawatan fungsional lepasan juga dapat memperbaiki profil wajah dengan retrognati mandibula menjadi profil yang ortognati karena reposisi mandibula ke anterior dalam hal ini bertambah majunya titik $B$, makin mengecilnya relasi mandibula dan maksila/ANB, peningkatan tinggi wajah bawah, koreksi overjet, peningkatan overbite, uprighting pada insisivus rahang atas, insisivus mandibula yang proklinasi, koreksi maloklusi dental Klas II, koreksi konveksivitas wajah, dan pengurangan lipatan mentolabial. 2,13

BeVicenzo menyatakan bahwa besarnya advancement sagital dapat merangsang sistem stomatologik dengan mempengaruhi pertumbuhan mandibula. Hasil penelitian menyatakan bahwa terdapat peningkatan panjang mandibula sebesar 2,5 $\mathrm{mm}$ 
dengan pemakaian piranti twin block. Lange dkk menyatakan bahwa terjadi peningkatan panjang mandibula sebanyak $6.4 \mathrm{~mm}$ pada kelompok piranti bionator. Pada pengukuran total panjang mandibula perlu mempertimbangkan perubahan posisi dagu ke depan karena adanya bias akibat rotasi mandibula searah jarum jam. McNamara dkk menyatakan bahwa peningkatan panjang mandibula pada piranti frankel oleh karena piranti ini tidak meningkatkan proyeksi dagu dibandingkan dengan kelompok kontrol, walaupun pada kelompok herbst menunjukkan efek tersebut. ${ }^{14-17}$

Haas dkk melakukan pengukuran total panjang mandibula dengan jarak linear dari articulare (Ar) ke pogonion (Pog). Titik articulare sering digunakan dalam perhitungan total panjang mandibula dibandingkan titik condylion (Co) oleh karena titik condylion sering tidak kelihatan jelas pada gambaran sefalometri. Akan tetapi, penentuan titik articulare sering mengalami kendala oleh karena titik tersebut merupakan perpotongan antara permukaan pharynx basis kranii dan permukaan posterior prosesus kondilus. Lokasi titik articulare sangat erat hubungannya dengan posisi mandibula. Pada kondilus yang lebih anterior, titik articulare akan kelihatan lebih posterosuperior pada bagian prosesus kondilus dan jarak Ar-Pog akan lebih panjang jika kondilus berada dalam fossa. ${ }^{9,18}$

Pada penelitian ini ditemui perubahan yang signifikan pada panjang korpus mandibula. Hasil serupa oleh Alió SJJ dkk yang menyatakan bahwa panjang korpus mandibula (Go-Gn) menunjukkan perbedaan signifikan sampel dengan piranti frankel. Nelson dkk menyatakan bahwa terdapat peningkatan panjang korpus mandibula (GoPog) dan pergerakan posterior Gonion (Go horizontal) yang berhubungan dengan adanya pertumbuhan. ${ }^{19-2}$

Pada penelitian ini ditemukan bahwa terdapat perubahan yang signifikan pada sudut SNB dan ANB. Lange dkk menyatakan bahwa terdapat peningkatan sudut SNB $1.0^{\circ}$ pada kelompok bionator dibandingkan kelompok kontrol. SNA menurun sebesar $0.5^{\circ}$ pada kelompok bionator dan meningkat $0.4^{\circ}$ pada kelompok kontrol. Pada kelompok bionator, terdapat pengurangan ANB sebesar 2.0 $0^{\circ}$.Perubahan pada mandibula dengan atau tanpa perubahan besar sudut SNA sering dijumpai pada perawatan piranti fungsional. Ristic dkk meneliti bahwa terdapat penurunan sudut SNA secara tidak signifikan setelah pemakaian piranti $M$ block dan frankel. Terdapat peningkatan sudut SNB dan SNPog secara signifikan pada kelompok $m$ block, frankel dan bionator. Dengan hasil ini terjadi penurunan sudut ANB. ${ }^{15,17,21}$

Pada penelitian ini terdapat peningkatan sudut dataran mandibula walaupun tidak signifikan. Nelson dkk menyatakan bahwa terdapat peningkatan besar sudut dataran mandibula pada kelompok activator dibandingkan kelompok kontrol maupun kelompok frankel. Jakobsson dkk melaporkan terjadi peningkatan sudut dataran mandibula pada kelompok activator dan tidak terdapat perubahan atau sedikit perubahan pada piranti frankel oleh karena tinggi gigitan yang lebih rendah pada piranti frankel. Martina dkk juga menemukan terdapat peningkatan dimensi vertikal setelah perawatan bionator. Freeman dkk menyimpulkan bahwa terdapat rotasi searah jarum jam yang tidak diinginkan pada maksila dan mandibula secara klinis dan statistik tidak signifikan pada piranti frankel. Ristic dkk menyatakan bahwa faktor yang paling penting untuk dipertimbangkan adalah tipe pertumbuhan wajah dan parameter vertikal sebelum perawatan. Kebanyakan 
pasien pada penelitian Ristic dkk memiliki pola pertumbuhan horizontal sehingga peningkatan nilai total analisis Bjork-Jarabak menyebabkan pertumbuhan alamiah pada akhir perawatan. ${ }^{20,21}$

\section{KESIMPULAN}

Perawatan maloklusi skeletal Klas II retrognati mandibula dengan mengunakan piranti fungsional lepasan usia tumbuh kembang dapat menambah total panjang mandibula dan panjang korpus mandibula sehingga diperoleh profil skeletal wajah yang ortognati. Penelitian ini memberikan informasi bahwa untuk koreksi maloklusi Klas II retrognati mandibula usia tumbuh kembang dapat memberikan hasil yang baik

\section{UCAPAN TERIMAKASIH}

Kami mengucapkan terima kasih kepada drg. Siti Bahirrah, Sp. Ort (K) atas bantuan dalam artikel ini.

\section{DAFTAR PUSTAKA}

1. Proffit WR, Fields HW, Sarver D. Contemporary Orthodontics, 5ed. St. Louis Missouri: Elsevier; 2013:386-402

2. Singh P. Textbook of Craniofacial Growth. New Delhi,India: Jaypee Brothers Medical Publishers (P) Ltd; 2011: 236-250

3. Oshagh M, Ghaderi F, Pakshirm HR, Baghmollai AM. Prevalence of malocclusions in school-age children attending the Orthodontics department of shiraz University of Medical Sciences. East Mediterr Heal J. 2010;16(12):1245-50.

4. Singh G. Textbook of Orthodontics. 2nd edition. New Delhi: Jaypee Brothers Medical Publishers (P) Ltd; 2007: 508-536

5. McNamara JJ, Brudon W. Orthodontics and Dentofacial Orthopedics. Ann Arbor: Needham Press; 2001:41-57

6. McNamara JA. Components of Class II Malocclusion In Children 8-10 Years of Age. Angle Orthod.1981;51:177-202.

7. Bishara SE. Textbook Of Orthodontics.
Philadelphia: W.B Saunders Company; 2001:324-374

8. Nasrin S, Sadat SMA. Growth Modification in Class II Malocclusion: A Review. Updat Dent Coll J. 2015;4(2):23-26.

9. Haas DW, Martinez F, Eckert GJ, Diers NR. Measurements of Mandibula Length : A Comparison of Articulare vs Condylion. 2001;71(3):210-215.

10. Rosenblum RE. Class II malocclusion: mandibula retrusion or maxillary protrusion? Angle Orthod.1995;65: 49-62.

11. Caldwell S, Cook P. Predicting the outcome of twin block functional appliance treatment: A prospective study. Eur J Orthod. 1999;21(5):533539.

12. Fleming PS, Lee R. Orthodontic Functional Appliances: Theory and Practice. Chichester, West Sussex: John Wiley \& Sons, Inc.; 2016:2849.

13. Wiltshire WA, Tsang S. A modern rationale for orthopedics and orthopedic retention. Semin Orthod. 2006;12(1):60-66.

14. Bevincenzo JP, Obispo SL, Winn MW. Changes in mandibula length before, during, and after successful orthopedic correction of Class II malocclusions, using a functional appliance. Am J Orthod Dentofac Orthod . 1989;96(3):181-190.

15. Lange DW, Kalra V, Broadbent BH, Powers M, Nelson S. Changes in soft tissue profile following treatment with the bionator. Angle Orthod. 1995; 65(6): 423-30.

16. Gill D, Sharma A, Naini F, Jones S.Twin Block Appliance For The Correction Of Class II Malocclusion. Dent Update. 2005;32: 158-68.

17. Collett AR. Current concepts on functional appliances and mandibula growth stimulation. Aust Dent J. 2000;45(3):173-178.

18. Shen G, Darendeliler MA. Cephalometric evaluation of condylar and mandibula growth modification: A review. Orthod Craniofacial Res. 2006;9(1):2-9

19. Alió-Sanz JJ, Kato E, Lorenzo-Pernía J, IglesiasConde C, Iglesias-Linares A, Solano-Reina E. Study of Mandibula Growth in Patients Treated with Frankel's Functional Regulator (1b). Med Oral Patol Oral Cir Bucal. 2012;17(5):884-895.

20. Nelson C, Harkness M, Herbison P. Mandibula changes during functional appliance treatment. Am J Orthod Dentofac Orthod. 1993;104:153161

21. Ristić V, Stefanović NL, Stamenković Z, Živković M. Effects of three types of functional appliances in Class II malocclusion treatment - sagittal and vertical changes. Srp Arh Celok Lek. 2018; 146:149-156 